\title{
'Elkaar zijn wij gegeven tot kleur en samenklank ...' Die rol van sang in die vorming en opbou van die geloofsgemeenskap
}

\author{
Author: \\ Elsabé Kloppers ${ }^{1}$ \\ Affiliation: \\ ${ }^{1}$ Department of Philosophy, \\ Practical and Systematic \\ Theology, University of \\ South Africa \\ Correspondence to: \\ Elsabé Kloppers \\ Email: \\ kloppec@unisa.ac.za \\ Postal address: \\ PO Box 392, University of \\ South Africa, Pretoria 0003, \\ South Africa \\ Dates: \\ Received: 11 May 2015 \\ Accepted: 25 July 2015 \\ Published: 14 Oct. 2015 \\ How to cite this article: \\ Kloppers, E., 2015, '“Elkaar \\ zijn wij gegeven tot kleur en \\ samenklank ..." Die rol van \\ sang in die vorming en opbou \\ van die geloofsgemeenskap', \\ HTS Teologiese Studies/ \\ Theological Studies 71(3), \\ Art. \#3036, 7 pages. http:// \\ dx.doi.org/10.4102/hts. \\ v71i3.3036

\section{Copyright:} \\ C 2015. The Authors. \\ Licensee: AOSIS \\ OpenJournals. This work is \\ licensed under the Creative \\ Commons Attribution \\ License.
}

Read online:

Scan this QR code with your smart phone or mobile device to read online.
The role of singing in the formation and building up of the community of faith. Faith is communicated through participation in various actions and rituals in a dynamic process of socialising into the Christian community. Worship is the prime locus for growing into the community of faith. The singing of hymns in worship is important for people to participate in the faith, to socialise into the Christian community and to strengthen the identity of the faith community. Flowing from worship and back, singing and making music, as gifts of the Holy Spirit, are relevant in all activities of the church: to celebrate, to proclaim the gospel, to teach the faith, to comfort and support people pastorally, to open up the opportunity for participation, to give space for communication, to reach out, to bring people together, to form community and foster koinonia - and in doing so, to contribute in building up the community of faith. The community of faith is sung into being. Making music and singing together therefore need to be a part of the encompassing program of a congregation and a church. Ministers need a thorough liturgical-hymnological training as a sound theological base for working with others in actively building up the community of faith through music.

\section{Inleiding en uitgangspunt}

Gemeentesang is 'n omvattende handeling wat die psigiese sowel as liggaamlike dimensies van menswees betrek. Deur gemeentesang word die persoonlike en kollektiewe dimensie van geloof verklank. In hierdie artikel word gevra na die moontlikhede wat sang bied om geloof oor te dra, identiteit te vorm, gemeenskap te stig, binding te bewerk, sosialisering te fasiliteer, koinonia te bevorder en die geloofsgemeenskap op te bou. Daar word gepoog om moontlike teologiese beginsels te ontsluit en riglyne vir die praktyk neer te lê. In aansluiting by vorige artikels oor die lied in die erediens (kyk Kloppers 2005, ook vir vroeër literatuur oor sang in die erediens) word verder gevra na ander terreine binne die kerk waar die kerklied en gemeenskaplike sang 'n rol kan speel om die geloofsgemeenskap te vorm en op te bou. In hierdie uitgawe word die 15-jarige bestaan van die Hervormde Teologiese Kollege (HTK) herdenk. Waar die HTK gerig is op die breë praktyk van kerk- en gemeente-wees, is dit gepas om in 'n artikel vir hierdie uitgawe te probeer bepaal hoe die lied vanuit die erediens breër in die werk en lewe van die kerk 'n bydrae tot opbou kan lewer.

Die artikel is gerig op die praktyk binne die breër konteks van die Reformatoriese kerke in SuidAfrika waar Afrikaans grootliks die voertaal is. Vir meer as 20 jaar reeds funksioneer ek (ook deur die Instituut vir Kerkmusiek in Suid-Afrika) binne hierdie breër konteks en poog om 'n bres te slaan vir die kerklied en die betekenis van kerksang, om 'n bewussyn vir die gepaste funksionering van die kerklied op te skerp en om begrip tussen kerkmusici en predikante te bevorder. Sekere beginsels vind egter moeilik inslag. Uit situasies in vele gemeentes en uit gesprekke kom dit voor asof predikante te dikwels meen net hulle werksaamheid spruit uit 'n 'ampsopdrag'. Daardeur verkry die priesterskap van alle gelowiges 'n mindere plek. Daarmee saam word die rol van musiek en die werk van kerkmusici in die verkondiging van die Woord van God en die opbou van die gemeente ook misgekyk. Die opleiding in die teologiese beginsels vir sang en die kerklied, in liturgies-himnologiese kompetensie as teologiese kompetensie, sowel as toerusting vir sinvolle samewerking met ander rolspelers, word steeds beskou as iets wat gesamentlik gereduseer kan word tot 'praktyk' en daarom gerelegeer kan word tot iets soos 'praktykvorming'. Die moontlikhede wat die lied in die erediens, sowel binne as daar buite - in die erediens van die lewe - tot verkondiging, viering, vertroosting, lering, diens en opbou bied, word nog nie diepgaande genoeg besef nie.

\section{Terreine van werksaamheid}

Gemeentes van die kerk van Christus funksioneer oral binne 'n bepaalde sosiale, kerklikkulturele, taal- en politieke konteks. Die kerk van Christus bestaan globaal, maar kom 
plaaslik tot uiting. Wat vir een kerk geld, kan nie sonder meer vir 'n ander geld nie. So lyk gemeentes binne ' $n$ kerk ook nie dieselfde nie. Die wesenseienskap en doel van kerk-wees oor die eeue en oor kerk- en landsgrense heen kan egter kollektief bepaal word as 'n gerigtheid op die oordra of 'aangee' van die geloof in Jesus Christus. Hierdie kommunikasie van die Evangelie met die oog op geloofsvorming geskied telkens binne 'n ander sosiale, kulturele en politieke konteks. Binne verskillende kerke, maar ook binne die terreine van die Pastorale Teologie en die Praktiese Teologie, word verskillende terreine van werksaamheid onderskei, maar nie altyd streng afgegrens nie. Grethlein volg byvoorbeeld 'n taamlik vrye indeling in sy Praktische Theologie (2012), terwyl Van der Ven (1993:13, 81-83) in 'n ouer werk 'n vyftal hoofterreine binne 'n streng sistematiese uiteensetting onderskei, naamlik liturgie, verkondiging (waarby die missionale dimensie ingesluit is), kategese, pastoraat en diakonie. Vir hom is dit vyf duidelike terreine van werksaamheid en kommunikasie in die kerk wat nie wedersyds tot mekaar gereduseer kan word nie. As Rooms-Katolieke teoloog wil Van der Ven waarskynlik juis die belang van die liturgie as viering, en dus nié bloot 'rasionele verkondiging' nie, beklemtoon. Dat liturgie en verkondiging onderskei word om daarmee die vieringsdimensie van die liturgie te beklemtoon is belangrik, juis waar die vieringsdimensie in die Afrikaanse reformatoriese kerke in 'n groot mate steeds ontken word en daar dikwels net op die prediking as 'n vorm van 'alleenverkondiging' gekonsentreer word. Aan die ander kant is die liturgie juis ook meer as viering: as geheel is die liturgie self óók verkondiging, waar elke deel kan en behoort by te dra tot die geheel van die verkondiging op 'n bepaalde tydstip en waar verskillende eredienste oor die tyd ook by mekaar kan aansluit. In dié opsig behoort daar weer nié 'n streng verdeling tussen liturgie en verkondiging te wees nie. Van der Ven se indeling het myns insiens waarde daarin dat hy gemeentebou nie as afsonderlike werkterrein indeel nie, maar meen dat die opbou van die gemeente organies uit elke funksie en terrein van die kerk se werksaamheid voortspruit.

Uit die afsonderlike terreine, maar samewerkend tot vorming van die geheel van 'n gemeente en 'n kerk se werksaamhede, kom die opbou van die kerk en gemeente tot gestalte. Verskeie onderafdelings, werksgebiede of temas kan binne terreine onderskei word en elkeen kan afsonderlik ondersoek word met die oog op die opbou van 'n gemeente en van die breër kerk. Spesifieke temas soos die stadskerk, teater, spiritualiteit en die werk met ouerwordende mense kan byvoorbeeld ook met die oog op gemeentebou ondersoek word (bv. Kunz 2001). Vir die doel van hierdie artikel word op die moontlike rol van kerksang in die opbou van die geloofsgemeenskap gefokus. Kerksang en die kerklied vorm primêr deel van die liturgie, as deel van die viering én as deel van verkondiging (na binne én na buite), maar funksioneer ook breër op die terreine van kategese, pastoraat en diakonie en kan op al hierdie terreine tot gemeenskapsvorming en die opbou van die gemeente bydra.

\section{Die sigbare gestalte van die geloofsgemeenskap}

Om in ' $n$ veranderende samelewing relevant te bly moet die kerk voortdurend sigbaar en hoorbaar gemaak word en moet lede moeite doen om dit waarvoor die kerk staan, geloofwaardig tot gestalte te bring in die wêreld (Grethlein 2012:378-413, 449-491). Verskillende beelde kan die gestalte van die kerk en die gemeente wat as gemeenskap saamkom, beskryf. Bybelse beelde soos 'volk van God', 'kinders van God', 'volgelinge van Jesus' word gebruik om identiteit aan te dui. Die vraag wat daarmee beantwoord word, is: Wie is ons? Volgens Van der Ven $(1993: 50,236)$ dui 'kinders van God' byvoorbeeld op 'n gemeenskap van broers en susters wat mekaar in 'n (gesins)verband aantref - broers en susters soek mekaar nie uit nie. Met verwysing na Moltmann (1975:341$344)$, toon hy aan dat die gemeenskap wat saamkom, ook as 'n 'gemeenskap van vriende' gesien kan word, daarin dat mense tot ' $n$ kerk kan toetree en as deel daarvan funksioneer op grond van 'n vrye, persoonlike beslissing. Beide beelde komplementeer mekaar: die gemeenskap van broers en susters, én die van 'n gemeenskap van vriende. Beide beelde dui op hartlikheid, gemeensaamheid en verbondenheid in die kerk. 'n Verdere religieuse beeld wat gebruik word om binding, gemeensaamheid, inklusiwiteit, uniformiteit (maar ook pluriformiteit) aan te dui, is die beeld van die 'liggaam van Christus'. Die teologiese uitgangspunt wat dié beeld ten grondslag lê, is dat mense bepaalde gawes van die Gees ontvang het om mekaar mee te dien en mekaar en die gemeente op te bou (Rom 1:11\&12; 12:3-8; 1 Kor 12 -14; Ef 4; 1 Pet 4:10). Hierdie beeld dui dus op aktiewe betrokkenheid by mekaar. Die werking van die Heilige Gees en die energie wat van die Gees uitgaan, vorm 'n kragveld waarin die ontvangers van die gawes, die draers van Gees - dus die begenadigde begaafdes - intree. Binne hierdie kragveld vorm hulle self weer kragvelde wat na buite werk en energie gee (Welker 1992:224-231). Deur die 'uitstraling' wat die Heilige Gees bewerk, deur die aktiewe betrokkenheid by mekaar, en deur die binding binne die kragveld van die Gees en van die geloof, kom die 'liggaam van Christus' tot stand en word gevoed en opgebou.

Betrokkenheid by mekaar en gestaltegewing geskied deur hoorbare en sigbare kommunikasie. Die gemeente kommunikeer met God, met mekaar en met 'n wêreld buite die mure van die kerkgebou. Deur religieuse beelde, soos aangetoon, en verder deur simbole en tekens, deur woorde en dade kommunikeer 'n kerk die kerk se religieuse identiteit, oortuigings, geloofsgrondslag, die doel en die taak van 'n kerk - konkreet na binne en na buite. Hierdie beelde en simbole verbind die individu en die geloofsgemeenskap en dit verbind die individu en die geloofsgemeenskap in gemeenskap met God. So kom die kerk as die gemeenskap van gelowiges (communio fidelium) tot stand. Die geloofsidentiteit van sowel die individu as dié van die geloofsgemeenskap bestaan nie in sigself nie - beide het 'n geskiedenis wat die kollektiewe herinnering (anamnese) vorm en wat die gemeenskap ten grondslag lê. Searle (1991) 
se waarneming dat dit nie soseer gaan om onderrig in wat gelowiges glo nie, maar om ingelyf(!) te word in wat hulle doen, het in die jare sedert hy die uitspraak gemaak het, aan relevansie toegeneem. Hy verwys na patrone van interaksie en kommunikasie wat 'n gemeenskap 'n spesifieke identiteit en karakteristieke etos gee:

Entering the community, one enters a world of meanings, communicated symbolically rather than discursively, by which one learns to make sense of the world and adopts appropriate attitudes and commitments in light of the founding religious experience from which the tradition sprang. To become a believer is not so much to be instructed in what believers believe as to be inducted into what believers do, into the patterns of interaction and communication that give the community its specific identity, its characteristic ethos. (Searle 1991:223)

Die gemeenskap van gelowiges is geleë in die verbondenheid aan en deelname van elk aan Christus die grond en oriënteringspunt van die kerk. Deur deel te neem, deur te doen, word ' $n$ mens deel van die wêreld van geloof en wat dit inhou. Dit beteken sosialisering in die geloofsgemeenskap in. Sosialisering of opvoeding in die geloofsgemeenskap in is eerstens die taak van die familie of huisgesin. Naas die huisgesin is die gemeente as geheel verantwoordelik vir geloofsvorming. Geloofsvorming is 'n deurlopende proses waar sosiale interaksie, deurleefde kennis en konkrete ervaring van alle betrokkenes 'n rol speel. Die rol van ervaringsgeörienteerde waarneming in geloofskommunikasie, asook die performatiewe aspek in religieuse vorming, word toenemend erken (Dressler, Kumlehn \& Klie 2012). Deur sosialisering, die toe-eiening van die tradisie en van geloofswaarhede en -waardes, vind identiteitsvorming plaas: identiteit as 'volk van God', 'kinders van God' of die 'liggaam van Christus'. Sosialisering bevorder ook die onderlinge binding en koinonia. Sosialisering is egter nie net na binne gerig nie. Dit vind plaas met die oog op die vorming van 'n deugsame geloofsgemeenskap wat op handeling na buite gerig is.

\section{Die erediens as ruimte waar geloof gevorm en aangegee word}

Kommunikasie na binne is noodsaaklik vir die voortgang en die opbou van die kerk. Kommunikasie na buite is weer bepalend vir die kerk om werklik kerk te wees, om gehoor, gesien en geglo te word. Met verwysing na Bonhoeffer wat die gemeente beskryf as die 'Gemeinde für andere' (Bethge, in Kloppers 2005:192), is vroeër reeds aangedui dat die gemeente vanuit die unieke byeenkoms van die erediens in die wêreld, na die wêreld, en terug na die erediens toe leef. Die kerk kom tot gestalte, word sigbaar gemaak in die erediens. Vanuit die liturgie in die kerkgebou word die kerk sigbaar - word Christus sigbaar in die liturgie van die lewe of die erediens van die lewe.

\footnotetext{
1.Die onlosmaaklike verband tussen die erediens en die 'erediens van die lewe' kan nie genoeg beklemtoon word nie. Die sterkste invloed om ' $n$ bewussyn daarvoor te skep binne die Suid-Afrikaanse konteks lê in die name vir die drie rubrieke van die Liedboek van die Kerk (2001) waarvoor ek en Louwrens Strydom gesamentlik verantwoordelik was (in aansluiting by nuwe gesangboeke uit Europa en die VSA): verantwoordelik was (in aansluiting by nuwe gesangboeke uit Europa en die VSA):
Die erediens, Die liturgiese jaar (die erediens deur die jaar) en die Erediens van die Die ere
lewe.
}

Waar geloof geleef en gekommunikeer word - in of buite die erediens - word daar aan elemente van die omringende werklikheid ('n situasie, gebeurtenis, handeling, proses) religieuse betekenis toegeken. Deur religieuse betekenisverlening verwys hierdie elemente na die teenwoordigheid van God se heil: dit be-teken, dit ver-teenwoordig God se werk in die wêreld. ${ }^{2}$ Outeurs soos Weyel (2011) en Schwier (2014:212) verwys na die ritueel van die erediens waar aan sekere handelinge, tekens en simbole in die erediens religieuse betekenis verleen word. Die simboolhandelinge in die ritueel van die erediens bied die moontlikhede vir 'n vorm van sosialisering waardeur die sosiale binding aan die kerklike gemeenskap en die simbole van die gemeenskap lewend gehou word. In die erediens groei mense in die simbole en 'taal' van die geloofsgemeenskap in en leer handelend die simbole en taal van die erediens in gemeenskap met ander. Die erediens, wat deur die gemeente as geheel gedra word (Marti 2014:31), is die primêre ruimte waar konkrete religieuse ervaring deur deelname opgedoen en oorgedra word. Searle (1991) se poëtiese beskrywing is tydloos:
Ritual participation is an entirely different way of relating to a religious tradition from, say, studying that tradition by reading about it or listening to lectures about it. Ritual does not merely make one think about religion. It makes one religious, in that it leads one of necessity to behave religiously, so that over time, and in company with the community, one gradually becomes formed as a religious person. It does not merely present the tradition; it enacts it. It claims not merely one's attention but one's commitment. It is self-involving. In participating, one gives oneself over to the conventions of a given community, adopting and appropriating the values, the myth, the Weltanschauung embodied in the rite. In ritual, above all, one appropriates the tradition in condensed, symbolic form and is socialized into the religious consciousness that is what ultimately constitutes the tradition. (Searle 1991:224; my kursivering)

In die erediensviering word die tradisie, die kollektiewe herinnering aan die heilsgebeure wat die geloofsgemeenskap ten grondslag lê, binne die breër geheel van die kerkjaar gestalte gegee en lewend gehou. Die erediens verbind mense met die geloofsvoorgeslagte, maar ook met toekomstige geslagte. In die Evangelisches Gottesdienstbuch (2005:15-17) van die Evangelisches Kirche in Deutschland (EKD) word sewe rigtinggewende teologiese kriteria vir die verstaan en vergestalting van die erediens gegee. Drie van die kriteria is hier veral van belang:

Die erediens is die verantwoordelikheid van die hele gemeente en gee geleentheid vir die deelname van die hele gemeente (verder ook Meyer-Blanck 2011; Mildenberger \& Ratzmann 2006).

Die taal mag niemand uitsluit nie, maar in die taal behoort die gemeenskap van sowel mans, vroue, jeugdiges en kinders, as dié van verskillende groeperinge, gepaste vorme van uitdrukking te vind (ook Meyer-Blanck 2012).

Liturgiese handeling en gedrag betrek die mens as geheel; dit bied geleentheid om ook liggaamlik en sintuiglik deel te neem. ${ }^{3}$

2.Hierdie is insigte wat spruit uit die invloed van die Semiotiek, vir die Liturgiewetenskap en Homiletiek, ontsluit deur onder meer Engemann (2011) en vroeër reeds Volp (1988).

3. Die betekenis van die liggaamlike handeling is ' $n$ belangrik onderwerp in die Liturgiewetenskap - kyk onder meer Friedrich 2001. 
Alhoewel die tweede punt wat hier genoem word, op taalgebruik fokus, beteken dit in praktyk dat niemand in die erediens uitgesluit mag voel nie; almal moet kan deelneem. Verder moet elkeen op verskillende vlakke van ervaring as geheelmense kan deelneem. In dieerediens, soosindieomgang met alle rituele, is die leer-verstaan nie die belangrikste nie, maar is die sosialisering, die meemaak, deurslaggewend. Dit het ook betekenis vir die sosialisering van kinders wat in die erediens en met die erediens grootword - van die begin af. Die Rooms Katolieke teoloog Albert Gerhards verwys na die liturgie as die leer- en lewensplek - 'Lern- und Lebensort' van die geloof (2012:209-216). Dit klink vanselfsprekend dat geloof deur die erediens aangegee word; tog wys Gerhards (2012:190) daarop dat die erediens dikwels geen, of bloot ' $n$ geringe rol speel in teologiese gesprekvoering oor die vraag na die 'Weitergabe des Glaubens', die aangee van die geloof. Hy verwys waarskynlik na sommige kringe in Duitsland waar godsdienspedagogiek en godsdiensdidaktiek só op die voorgrond staan dat daar nouliks meer 'n bewussyn vir die rol van die erediens is. Dit gebeur egter ook toenemend in kerke in Suid-Afrika waar kinders grootliks buite die erediens met iets anders besig gehou word. Binne die Suid-Afrikaanse situasie moet die besef nog deurwerk dat die erediens waarin kinders ruimte het, noodsaaklik is vir die oordrag van die Christelike geloof.

Die wesenlike vraag is nie of kinders die gebeure van die erediens met die verstand verstaan nie, maar of hulle 'daar' is, teenwoordig is, of hulle deel is van die ervaring van daarwees en saam met die 'volwassenes' mag deelneem aan die ritueel van herinnering en oorlewering, in die spanning van verlede, hede en toekoms. Dit gaan om die gevoel van welkom-wees; om aangespreek te word deur aspekte wat juis nie onder woorde gebring kan word nie; om die geleidelike deel-word van en ingroei in die geloofsgemeenskap in; om die mooiheid van 'n kerkruimte waar te neem ${ }^{4}$, die andersheid daarvan te ervaar - die besondersheid teenoor die alledaagse; om geleidelik te leer om die aandag toe te spits; om die sakrament van die doop waar te neem en die water te hoor; die nagmaalgebeure te ervaar, die wyn te ruik; met verwondering die glans van die ligte in die ruimte waar te neem, die lig deur loodglasvensters te sien skyn, of die warmte van die kerse te voel; om betower te word deur 'n lied wat met passie gesing word ...

Die deure vir die erediens behoort vir almal oop te staan: alle mense en alle generasies moet welkom voel. In die erediens vloei die onderskeie dienste en werksaamhede van die gemeente saam. Die erediens simboliseer eenheid in die veelheid. Die erediens vorm die geloofsmiddelpunt van die communio sanctorum. Vanuit die erediens word die deure na buite geopen, word die Evangelie uitgedra en word die verantwoordelikheid vir die wêreld waargeneem. Die geloofsgemeenskap leef uit die erediens na die wêreld toe en kom uit die wêreld weer terug in die erediens. So word die missionale dimensie van die erediens 'n werklikheid.

\section{Verkondiging, sosialisering en koinonia deur die kerklied}

\author{
Gottesdienste sind Rituale, für die auch symbolische \\ Kommunikationsformen und die Partizipation aller \\ Teilnehmenden benötigt werden, womit nicht nur eine aktive \\ äußere Beteiligung gemeint ist. Der Gemeindegesang ist dabei \\ wohl das gewichtigste Medium äußerer wie innerer Beteiligung \\ im Gottesdienst. (Schwier 2014:212)
}

In die ritueel van die erediens bied die sang as simboliese uitdrukking (kommunikasievorm) die geleentheid tot aktiewe deelname, innerlik en uiterlik, wat nie deur enige ander handeling geëwenaar word nie. In die deelname aan die sang vind geloofsvorming en identiteitsvorming plaas. Die erediens en die sang in die erediens bied 'n vorm van sosialisering waardeur mense in die geloof van die geloofsgemeenskap ingroei en so die simbole en unieke wyses van kommunikasie leer verstaan en ook deel daarvan word. Geloofsbeginsels word oorgedra, daar word verkondig, 'God se woord' word uitgedra. In dié verband is Luther se siening van musiek as medium vir verkondiging belangrik. Hy gee musiek die eerste plek náás die teologie, omdat hy die verkondigingswaarde daarvan besef het. In sy rede met die inwyding van die kerk in Torgau in 1544 (Sonderdruck, in privaatbesit, maar ook in Weimarer Ausgabe - WA 49:588) sê hy dat die lied gebed en lofsang kan wees, maar dat dit in die uitvoering ook God se heilige Woord kan word. As verkondiging in velerlei gestaltes kan die kerklied soms selfs sterker as die gesproke woord funksioneer. In die sang en deur die sing van 'n kerklied word die kerk as kerk 'hoorbaar'.

Sang gee gestalte aan die saamhoort van 'n verskeidenheid van uiteenlopende mense in die één geloof. Deur die sing van die liedere wat 'aangebied' en ontvang word, kan gelowiges fisies die draers word van betekenis wat toegeëien word, maar wat ook weer aan ander aangebied word. Gemeensaamheid word so gekonstitueer. Hierdie inlywing en integrering in die simboolwêreld van die liturgiese gemeenskap en só in die geloof in, vind binne die erediens plaas, maar ook verder by geleenthede buite die erediens waar die gemeente as geloofsgemeenskap saam is, of waar die individu die lied van die geloof aanhef. Te midde van die klem op individualisme het mense ook 'n wesenlike behoefte aan gemeensaamheid. Die lied van die geloof wat saam met ander aangehef word, het bindende krag. Dit is gerig op gemeensaamheid en kan juis die eensaamheid deurbreek. Die kerklied kry klank en transendeer mense se gebrokenheid. Dit kan as helende balsem werk. Waar die kerklied gesing word - ook buite die kerk - kan die helende krag werksaam word. 'n Siek of sorgbehoewende persoon wat vanweë omstandighede fisies verwyderd is van die geloofsgemeenskap kan deur die geestelike lied te sing of te hoor, steeds aan die geloofsgemeenskap gebind word en die krag ervaar wat daarvandaan uitgaan. In 'n vroeër artikel is reeds aandag gegee aan die pastorale werking van die kerklied (kyk Kloppers 2000; ook Klessmann [2005] 2006). Die Nederlandse lieddigter, Sytze de Vries 
(2009:10) verwoord hierdie werking treffend in 'n liedteks. In die eerste strofe verwys hy na die gemeensaamheid in die viering van die liturgie: ons is aan mekaar gegee tot 'samenklank', tot harmonie. Ons sing die lofsang om die lewe. In die tweede en derde strofe gaan dit om die pastorale werking van die lied:

Zolang wij ademhalen schept Gij in ons de kracht om zingend te vertalen waartoe wij zijn gedacht: elkaar zijn wij gegeven tot kleur en samenklank. De lofzang om het leven geeft stem aan onze dank.

$\mathrm{Al}$ is mijn stem gebroken, mijn adem zonder kracht, het lied op and're lippen draagt mij dan door de nacht ...

\section{Samesang en samewerking tot opbou van die gemeente}

Musiek verkondig naas die prediking. So redeneer Andreas Marti, Gereformeerde teoloog, himnoloog en praktiserende kerkmusikus in Switserland, dat daar ook van die amp van kerkmusikus sprake behoort te wees. Hy gebruik die begrip amp in afgrensing van predikante wat teenoor kerkmusici sou optree, asof slegs predikante 'n 'amp' sou beklee; ook in afgrensing van die minagtende wyses waarop soms met die kerklied en kerkmusiek omgegaan word. Hy onderskei die volgende sake met betrekking tot die funksie van kerkmusiek en die 'amp van kerkmusikus':

Die amp van kerkmusiek is 'n geordende gemeentebouende diens, wat gegrond is op goddelike genadegawes.

Die besondere diens van die kerkmusikale amp is die diens van lof en dank - dus die diens wat die gemeente in die regte verhouding met God kan stel. (Naas lofprysing kom ook die klag en smeking ter sprake.)

Kerkmusiek staan in die eerste plek binne die verloop van die erediens van die gemeente en vorm ook deel van die verloop. Die kerkmusikus se taak word dus primêr binne die erediens vervul. (Die primêre, nie die enigste plek nie - EK.)

Kerkmusiek is belydend. Dit kom tot uiting in die grondliggende diens van die kerk, naamlik die diens van die Woord. Die kerkmusikus het dus ook deel aan die diens van die Woord.

Die kerkmusikus se taak kom eers daar tereg, waar dit in noue samewerking met al die ander ampte geskied en waar sy/hy lid is van die gemeente wat die algemene priesterskap van die gelowiges as die uitgangspunt van alle werksaamhede neem. (Marti 1989:10-11)

Marti neem 'n ampsbegrip wat spruit uit die beginsel van die priesterskap van alle gelowiges as uitgangspunt. In die gemeente behoort alle gelowiges die geleentheid te kry om hulle genadegawes te gebruik tot diens en wedersydse opbou van mekaar. Musiek in die erediens en in aansluiting by die erediens behoort deel te vorm van die verantwoordelikheid en betrokkenheid van elke begaafde gelowige - in die letterlike sin van die woord bedoel. Die liturg behoort die persoon te wees met die eerste verantwoordelikheid ten opsigte van die inrigting van die liturgie en die keuse van liedere, maar het die opdrag om juis ook soveel mense moontlik te betrek, hulle verantwoordelikheid vir die erediens te versterk en die kompetensie van alle deelnemers te help bevorder. In alles behoort die geloofservaring en lewenservaring van gemeentelede ook na waarde geskat te word (Schwier 2014:211).

Vanuit die erediens kan sang 'n rol tot opbou op al die terreine in die geloofsgemeenskap speel - naas die liturgie en die verkondiging, ook in die kategese op die Sondag en in die week, in die pastoraat, in die werk met verskillende groepe, by vergaderings, Bybelstudiegeleenthede, gemeente-byeenkomste, kleingroep- of kringbyeenkomste, jeuggeleenthede en ander byeenkomste. By al hierdie geleenthede kan koinonia deur die kerklied bewerk word. 'n Gees van liefde en koinonia skep die ruimte vir aanpassing, identiteitsvorming, integrasie en positiewe verandering faktore wat die gemeente as geheel, sowel as die individu in die geloof kan versterk en opbou. Die sang in die erediens behoort dus uit te mond in geleenthede waar die identiteit en konkrete werksaamheid van die gemeente in groepverband verdere gestalte kry. Groepe in 'n gemeente kan saamkom om gesprek oor die kerklied te voer, oor die plek en funksionering van die lied in die gemeente te besin, te vra wat liedere sê en hoe hulle dit sê - en vanselfsprekend, met die oog daarop om te sing. ' $n$ Wye verskeidenheid van liedere wat elkeen in 'n bepaalde lewensfase aanspreek, behoort gesing te word, sodat die volle spektrum van deelnemers in berekening gebring word. Die voortgaande belang van sang in die erediens en breër, blyk uit 'n omvattende empiriese studie wat in die onlangse verlede in die EKD Duitsland gedoen is (kyk Danzeglocke et al. 2011). ${ }^{5}$

Die moontlikhede van 'n kerkmusikale praktyk wat in sowel die gemeentesituasie, as in die maatskaplike omgewing ingebed is, en wat van daaruit wyer uitkring, moet nog ontdek en beproef word (Arnold 2011 in geheel). Die kerk het medewerkers nodig wat die moeilike eise van veranderende tye kan hanteer. Dit geld in die besonder vir die medewerkers op die terrein van kerkmusiek. Samewerking en wedersydse betrokkenheid is belangrik. Belangrik is die neem van verantwoordelikheid ten opsigte van die erediens en musiek op alle vlakke van die gemeente en in die breër kerklike struktuur. In elke gemeente behoort bestaande musikale gawes ontdek en uitgebou te word om in diens van die volle gemeentelewe te staan. Die opleiding en voortdurende verdere opleiding van alle medewerkers is noodsaaklik. Die leiding kan in die eerste plek geneem word deur opgeleide en toegewyde kerkmusici wat met ander betrokkenes saamwerk om 'n lewende gemeente op te bou. Besondere vaardighede word van musiekleiers vereis: die vermoë tot goeie kommunikasie, goeie luistervermoë, die bereidheid om te leer, 'n terapeutiese en versorgende ingesteldheid, sowel as pedagogiese kompetensie (Kirschbaum [2005] 2006:199-205). In die vele fasette van 'n gemeente se funksionering kan verskillende

5.Die ondersoek na sang in die erediens het plaasgevind van Desember 2008 tot Februarie 2009 en het onder meer gefokus op vrae na die voorkeure van tot Februarie 2009 en gemeentelede, diemusiekgenreswathulleverkies, wat sang vir hullebeteken, waar en wanneer hulle sing, praktyke van sang in die erediens, wat hulle van die kerklied verwag en watter soort begeleiding hulle sou verkies. 
persone per geleentheid leiding neem met gemeenskaplike musiek maak of sang: naas die orrelis en ander 'amptelike' musiekleiers, ook kategete, predikante, jeugwerkers, seniorgroepleiers, diensgroepe, jongmenseén ouer mense wat instrumente kan bespeel. Ook die werking in die omringende kultuur, die breër maatskaplike verantwoordelikheid deur hierdie diakonale werksaamhede, die dienswerk aan die medemens, moet in die oog gehou word.

Nuwe liedere en nuwe erediensvorme behoort ook voortdurend aandag te geniet. Die kerk en die kerklied behoort voortdurend te vernuwe en aan te pas by die eie tyd. Dit is egter ook noodsaaklik dat die musiek pastoraal sensitief ten opsigte van die feesvierende gemeenskap moet wees en dat dit ' $n$ vorm en moeilikheidsgraad reflekteer wat gepas is ten opsigte van die deelnemers (kyk Kloppers 2013 ten opsigte van die grense van opname). Die verwysingsveld en behoefte van die gemeente mag nie geïgnoreer word nie. Daar mag egter ook nie bloot by die 'smaak' van 'n gemeente vasgesteek word nie: 'n gemeente word ook geroep om te verander - om meer te leef soos Christus ons voorgeleef het. Sang kan meewerk aan hierdie verandering. Die persoonlike vermoë en smaak van diegene wat verantwoordelik is vir die gestaltegewing van die erediens, mag ook nie tot die norm verhef word nie. Die gemeente en die liturge se verwysingsraamwerk vir kerkmusiek kan ontwikkel word deur 'n breër blootstelling, deur die luisterervaring uit te brei en in die besonder deur aandag aan die musikale handeling, die 'doen-ervaring' te gee. Weens 'n toenemende gebrek aan blootstelling aan die kerklied en weens die gebrek aan aktiewe samesang in baie gemeenskappe (Bubmann 2012:215-224), het gemeentes kundige aanmoediging en leiding tot sang en nuwe wyses van sang nodig. Om aandagtig te luister, diep in te adem, om klag te laat hoor sowel as bevrydend te jubel - om werklik feestelik fees te vier, is die teken van 'n lewende gemeente.

\section{Liturgies-himnologiese opleiding en vorming}

Die grondige opleiding van predikante in die sistematiesteologiese en trinitaries-gefundeerde grondslae van die liturgie, en daarby aansluitend die teologiese beginsels van die kerklied, kan dus nie sterk genoeg beklemtoon word nie. Dat hierdie opleiding in teologiese beginsels nié afgeskuif mag word na iets soos 'praktykvorming' nie, of dat praktiserende kerkmusici (hoe goed ook al opgelei) nié die verantwoordelikheid vir die teologiese onderrig in die liturgie en kerklied behoort te neem nie, is vanselfsprekend. Onderrig op die omvattende terrein van die himnologie verg naas die musiek-, taal-, en literatuurwetenskappe, ook deeglike kennis van die Bybelwetenskappe en die pluralisme van eksegetiese en hermeneutiese metodes, van die sistematiese teologie en etiek, van die ontwikkelings van die lied en die liturgie deur die geskiedenis, en vanselfsprekend ook van die teologie van die erediens. Soos Reich (2003:774) aantoon: 'Die himnologie is ' $n$ interdissiplinêre en konsekwent ekumeniese wetenskap.' Die liturgies-himnologiese opleiding hoort dus by teoloë wat deeglik op die terreine van die Liturgiewetenskap én Himnologie onderlê is - soos daar vir alle ander terreine van die teologie deeglik opgeleide vakkundiges verwag word. Himnologie behoort náás 'n vak soos Homiletiek as 'n onafhanklike teologiese vak gesien te word waarvoor net soveel tyd in die teologiese opleiding ingeruim behoort word.

Die kerklied het met die hart van die gemeente te doen. Dit is die lewegewende polsslag waaruit die gemeente leef, gevoed en opgebou kan word. Eers ná grondige teologiese toerusting om die anamnetiese, epikletiese, doksologiese, kategetiese, diakonale en pastorale werking van die erediens en die lied te begryp kan ook gefokus word op die praktykgerigte inrigting van die liturgie en die lied in die liturgie. Te midde van die pluraliteit van aanbiedings in die huidige tydsgewrig is die vorming tot onderskeidingsvermoë binne so 'n praktykgerigte situasie ook 'n uiters belangrike saak. Verbind met die lied en musiek, behoort ook die benutting van ander kunsvorms aandag te kry om toekomstige liturge aan die moontlikhede bloot te stel waardeur die gemeente op verskillende vlakke deur die estetiese dimensie opgebou kan word (Gerhards 2012:142-189; Meyer-Blanck 2011:343387; Nicol [2009] 2010:163-169). Die Heidelbergse teoloog, Helmut Schwier (2014:213) pleit dat die dimensies van gemeenskaplike viering, simbolies-rituele kommunikasie en handelinge, van kerkruimtes en van kunsuitings soos musiek, beeldende kuns, loodglaswerk en bewegingskuns, nuut ontdek en nuut ontgin moet word.

\section{Die gemeenskap wat nie sing nie, is nié die gemeenskap nie ...}

Sang maak die communio sanctorum hoorbaar. Sosialisering, deelname en gemeenskapsvorming deur die kerklied dra in 'n besondere mate by tot die aanneem van die geloofstradisie, die vorming van die identiteit van die geloofsgemeenskap, die groei in die geloofsgemeenskap in en die koinonia van gelowiges. Deur die krag van gemeentesang kan die individu opgebou en die binding tot 'n gemeenskap van gelowiges bewerk word wat ook invloed na buite uitoefen. Die bewussyn vir die vele moontlikhede tot opbou van die gemeente wat rondom gemeentesang as vorm van geloofskommunikasie bestaan, behoort dus doelbewus uitgebou te word sodat elkeen aangespoor kan word om die gawes van die Gees aan te neem en te gebruik en om aktief deel te neem tot opbou van die gemeente as die één liggaam van Christus, as broers en susters van mekaar, as vriende onder mekaar, as die huisgesin van God, as die gemeenskap van gelowiges wat ook in die breër gemeenskap en omringende kultuur positiewe verandering kan bewerk.

Wat ons met redelike sekerheid kan en moet sê, is dat die gemeenskap wat nie sing nie, nié die gemeenskap is nie. En waar dit nie in lewende spreke kan sing nie, maar slegs argaïes, in herhaling van wyses van sing en tekste uit die verlede - waar 'n gemeenskap nie werklik sing nie, maar sug en ongemaklik mompel, kan dit ten beste slegs 'n vertroebelde gemeenskap wees wat nie van die eie saak seker is nie en van wie se bediening nie veel verwag kan word nie. In hierdie omstandighede het die gemeenskap alle rede om te bid dat die gawe wat ontbreek, of 
wat slegs in beperkte mate geniet word, opnuut gegee sal word en meer vrygewig, want so nié sal alle lede daaronder ly. Die lof van God wat die konkrete hoogtepunt in die sang van die gemeente vind, is een van die noodsaaklikste basiese vorms van die bediening van die gemeente. (Karl Barth [1959] 1961, III 2:994, Eng. 1961:865 [Afrikaanse vertaling Kloppers])

\section{Erkenning \\ Mededingende belange}

Die outeur verklaar dat sy geen finansiële of persoonlike verbintenis het met enige party wat haar nadelig kon beïnvloed in die skryf van hierdie artikel.

\section{Literatuurverwysings}

Arnold, J., 2011, 'Musik und Gottesdienst - Musik im Gottesdienst', in H-J. Eckstein U. Heckel \& B. Weyel (Hg.), Kompendium Gottesdienst. Der Evangelische Gottesdienst in Geschichte und Gegenwart, pp. 224-244, Mohr, Tübingen.

Barth, K. [1959] 1961, Church Dogmatics, transl. G.W. Bromiley, vol. 4, part 3/2: The Doctrine of Reconciliation. Clark, Edinburgh.

Bubmann, P., 2012, 'Singen im Protestantismus heute und morgen - Problemanzeigen und Chancen', in P. Bubmann \& K. Klek (Hg.), Davon ich singen und sagen will: Die Evangelischen und ihre Lieder, pp. 215-224, Evangelische Verlagsanstalt, Leipzig.

Danzeglocke, K., Heye, A., Reinke, S. \& Schroeter-Wittke, H. (Hg.), 2011, Singen im Gottesdienst. Ergebnisse und Deutungen einer empirischen Untersuchung in evangelischen Gemeinden, Gütersloher Verlagshaus, Gütersloh.

De Vries, S., 2009, Jij, mijn adem. Verzamelde liederen, Boekencentrum, Zoetermeer.

Dressler, B., Kumlehn, M. \& Klie, T., 2012, Unterrichtsdramaturgien. Fallstudien zur Performanz religiöser Bildung, Kohlhammer, Stuttgart.

Engemann, W., 2011, Einführung in die Homiletik, 2.Auflage, UTB, Stuttgart.

Evangelisches Gottesdienstbuch, 2005, Agende für die EKU und für die VELKD, Verlagsgemeinschaft Evangelisches Gottesdienstbuch, Berlin.

Friedrich, M., 2001, Liturgische Körper. Der Beitrag von Schauspieltheorien und -techniken für die Pastoralästhetik, Kohlhammer, Stuttgart.

Gerhards, A., 2012, Erneuerung kirchlichen Lebens aus dem Gottesdienst. Beiträge zur Reform der Liturgie, Kohlhammer, Stuttgart.

Grethlein, C., 2012, Praktische Theologie, Walter de Gruyter, Berlin.

Kirschbaum, C., [2005] 2006, 'Singen in der Gemeinde als Bildungsarbeit', in G. Fermor \& H. Schroeter-Wittke (Hg.), Kirchenmusik als religiöse Praxis. Praktischtheologisches Handbuch zur Kirchenmusik, pp. 199-205, EVA, Leipzig.

Klessmann, M., [2005] 2006, 'Kirchenmusik als Seelsorge', in G. Fermor \& H. Schroeter -Wittke (Hg.), Kirchenmusik als religiöse Praxis. Praktisch-theologisches Handbuch zur Kirchenmusik, pp. 230-234, EVA, Leipzig.
Kloppers, E., 2000, 'Ubi caritas et amor deus ibi est: Die pastorale funksie van die kerklied', Praktiese Teologie in Suid-Afrika 15(2), 99-111.

Kloppers, E., 2005, 'Handelinge in die erediens: Die verryking van die liturgie deur musiek', HTS Teologiese Studies/Theological Studies 61(1/2), 165-190. http:// dx.doi.org/10.4102/hts.v61i1/2.446 (In verkorte vorm opgeneem in Diensboek 2008, Pretoria: Sentik.)

Kloppers, E., 2013, "n Lied moet klink om gehoor te word ... Faktore wat die resepsie van kerkliedere kan beïnvloed', HTS Teologiese Studies/Theological Studies 69(1) Art. \#1351, 8 pages. http://dx.doi.org/10.4102/hts.v69i1.1351

Knecht, A., 2011, Erlebnis Gottesdienst. Zur Rehabilitierung der Kategorie 'Erlebnis' für Theorie und Praxis des Gottesdienstes, Evangelische Verlagsanstalt, Leipzig.

Kunz, R. (Hg.), 2001, Gemeindeaufbau konkret. Arbeitsfelder einer lebendigen Kirche, TVZ, Zürich.

Liedboek van die Kerk, 2001, NG Kerk Uitgewers, Kaapstad.

Marti, A., 1989, 'Geleitwort', in Institut für Kirchenmusik der evangelisch-reformierten Landeskirche des Kantons Zürich (Hg.), Musik in der evangelisch-reformierten Kirche: Eine Standortbestimmung, pp. 9-14, TVZ, Zürich.

Marti, A., 2014, Wie klingt reformiert? Arbeiten zu Liturgie und Musik, TVZ, Zürich.

Meyer-Blanck, M., 2011, Gottesdienstlehre, Mohr Siebeck, Tübingen.

Meyer-Blanck, M. (Hg.), 2012, Die Sprache der Liturgie, Evangelische Verlagsanstalt, Leipzig.

Mildenberger, I. \& Ratzmann, W. (Hg.), 2006, Beteiligung? Der Gottesdienst als Sache der Gemeinde, Beiträge zu Liturgie und Spiritualität 15. Evangelische Verlagsanstalt, Leipzig.

Moltmann, J., 1975, Kirche in der Kraft des Geistes. Ein Beitrag zur messianischen Ekklesiologie, Kaiser, München.

Nicol, M. [2009] 2010, Weg im Geheimnis: Plädoyer für den Evangelischen Gottesdienst, 3. Auflage, Vandenhoeck \& Ruprecht, Göttingen.

Pohl-Patalong, U., 2011, Gottesdienst erleben. Empirische Einsichten zum evangelischen Gottesdienst, Kohlhammer, Stuttgart.

Reich, C., 2003, 'Kirchenlied', in H.C. Schmidt-Lauber, M. Meyer-Blanck \& K-H. Bieritz (Hg.), Handbuch der Liturgik, 3. Auflage, Vandenhoeck, Göttingen.

Rupp, H. (Hg.), 2006, Handbuch der Kirchenpädagogik. Kirchenräume wahrnehmen, deuten und erschließen, Kohlhammer, Stuttgart.

Schwier, H., 2014, 'Der evangelische Sonntagsgottesdienst - vom Strukturpapier zum Evangelischen Gottesdienstbuch', in A. Gerhards \& M. Schneider (Hg.), Der Gottesdienst und seine Musik, Teilband 2, Liturgik: Gottesdienstformen und ihre Handlungsträger, Enzyklopädie der Kirchenmusik Bd. 4, pp. 207-215, Laaber.

Searle, M., 1991, 'Two liturgical traditions: Looking to the future', in P.F. Bradshaw \& L.A. Hoffman (eds.), The changing face of Jewish and Christian worship in North America, pp. 221-243, University of Notre Dame Press, Notre Dame.

Van der Ven, J.A., 1993, Ecclesiologie in context, Kok, Kampen.

Volp, R., 1988, Zeichen. Semiotik in Theologie und Gottesdienst, Kaiser, München.

Welker, M., 1992, Gottes Geist. Theologie des Heiligen Geistes, Neukirchen-Vluyn, Neukirchen.

Weyel, B., 2011, 'Der Gottesdienst als Ritual', in H-J. Eckstein, U. Heckel \& B. Weyel (Hg.), Kompendium Gottesdienst. Der evangelische Gottesdienst in Geschichte und Gegenwart, pp. 166-184, Mohr Siebeck, Tübingen. 